\title{
Correction to: Solution Chemistry of Arsenic Anions in the Presence of Metal Cations
}

\author{
Julia Torres $^{1}$ D $\cdot$ Patricia Santos $^{1} \cdot$ Carolina Ferrari $^{1} \cdot$ Carlos Kremer $^{1}$ • \\ Eduardo Kremer ${ }^{1}$
}

\section{Correction to: J Solution Chem https://doi.org/10.1007/s10953-017-0699-3}

The original version of this article unfortunately contained a mistake in the last author's name. The co-author's name should be Eduardo Kremer instead of Eduardo Kremerv.

The original article has been corrected.

The original article can be found online at https://doi.org/10.1007/s10953-017-0699-3.

\section{Julia Torres}

jtorres@fq.edu.uy

1 Cátedra de Química Inorgánica, Departamento Estrella Campos, Facultad de Química, Universidad de la República, 1157 Montevideo, Uruguay 